\title{
Ontogeny and morphology of Cambrian eocrinoid Akadocrinus (Barrandian area, Czech Republic)
}

\author{
MARTINA NOHEJLOVÁ \& OLDŘICH FATKA
}

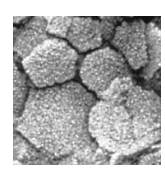

\begin{abstract}
The gogiid eocrinoid Akadocrinus jani Prokop, 1962 is known from the mid-Cambrian (Drumian) Jince Formation of the Př́bram-Jince Basin (Barrandian area, Czech Republic). Excellently preserved specimens of this species are described in detail. Our primary focus was on juvenile specimens, described here for the first time. Detailed comparison among juvenile specimens makes it possible to establish changes in morphology during ontogeny. Juvenile specimens differ considerably from adult specimens in (1) a lower number of thecal plates, (2) a complete absence of epispires, (3) comparatively shorter brachioles, comprising a small number of brachiolar plates, (4) a comparatively shorter stem, comprising a small number of columnals and (5) a relatively large attachment disc. Study of the Jince material makes it possible to establish two basic phases in the development of Akadocrinus: the pre-epispire bearing phase and the epispire bearing phase. - Key words: Akadocrinus, Eocrinoidea, mid-Cambrian (Cambrian Series 3), Př́bram-Jince Basin, Barrandian area, Czech Republic.
\end{abstract}

NOHEJLOVÁ, M. \& FATKA, O. 2016. Ontogeny and morphology of Cambrian eocrinoid Akadocrinus (Barrandian area, Czech Republic). Bulletin of Geosciences 91(1), 141-153 (9 figures, 2 tables). Czech Geological Survey. Prague, ISSN 1214-1119. Manuscript received August 27, 2015; accepted in revised form January 19, 2016; published online March 15, 2016; issued March 17, 2016.

Martina Nohejlová \& Oldřich Fatka, Charles University, Institute of Geology and Palaeontology, Albertov 6, 12843 Prague 2, Czech Republic; martina.nohejlova@natur.cuni.cz, fatka@natur.cuni.cz.

The Cambrian was an important period in the evolution of echinoderms as during that time they originated and underwent their initial diversification, which established many of their major clades. The record of Cambrian echinoderms includes nearly 200 species classified into eight major groups: helicoplacoids, eocrinoids, edrioasteroids, rhombiferans, cinctans, ctenocystoids, solutans and stylophorans (Zamora et al. 2013).

Eocrinoids represent one of the main echinoderm groups in Cambrian associations (Sprinkle 1973). It is a paraphyletic class of basal blastozoans (Sprinkle 1973, Smith 1984). The body of eocrinoids is usually composed of three major parts: (1) erect biserial brachioles, (2) polyplated theca, (3) stem used for attachment and to elevate the theca above see sea floor (see Fig. 1). The oldest occurrence of the class Eocrinoidea is from Cambrian Stage 4 in Laurentia (Durham 1978), and both East and West Gondwana (South China, see Zhao et al. 2007, Hu et al. 2007, $\mathrm{Hu} \&$ Luo 2008; Spain and Morocco, see Ubaghs \& Vizcaïno 1990, Nardin \& Lefebvre 2005, summary in Zamora et al. 2013). During the mid-Cambrian, eocrinoids reached their maximum diversity (Sprinkle 1973, Sprinkle et al. 2011). Their numbers and diversity declined steadily from the late Cambrian until their extinction in the Silurian (Sprinkle 1973, Zhao et al. 2008).
Cambrian eocrinoids have been reported from North and Central America, Europe, North Africa, East Asia, Australia and Siberia (Yakovlev 1956, Sprinkle 1973, Jell et al. 1985, Parsley \& Zhao 2006, Zamora et al. 2013).

Echinoderms show great diversity in the Cambrian of the Barrandian area. Disarticulated remains of eocrinoids are quite abundant in Cambrian sediments in this area, while remains of more complete specimens have been documented less often. From the Barrandian area, the following five eocrinoid genera have been described: Lichenoides Barrande, 1846; Acanthocystites Barrande, 1887; Akadocrinus Prokop, 1962; Luhocrinus Prokop \& Fatka, 1985 and Vyscystis Fatka \& Kordule, 1990 (see Nohejlová \& Fatka 2015); a sixth genus, Cigara Barrande, 1887 is also found there, but its systematic position is still uncertain (see Lefebvre \& Fatka 2003, Fatka \& Szabad 2014b).

Our study is focused on a detailed morphological description of several tens of well- to excellently-preserved specimens of Akadocrinus Prokop, 1962 from Cambrian deposits in the Prríbram-Jince Basin. Prokop (1962) established two species of the genus Akadocrinus: A. jani Prokop, 1962 and A. nuntius Prokop, 1962, both originating from the same stratigraphic level within the Jince Formation. However, Sprinkle (1973) concluded that these two 


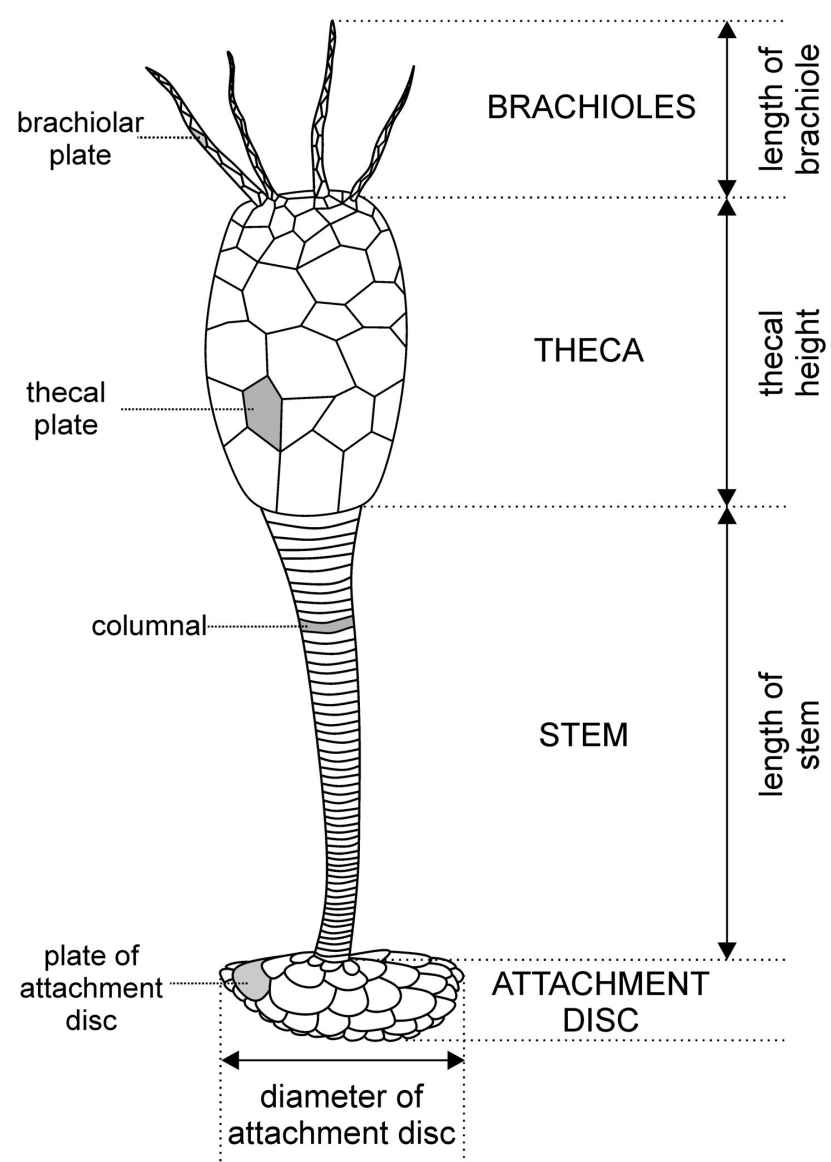

Figure 1. Reconstruction of morphology of a juvenile specimen of Akadocrinus jani Prokop, 1962 showing morphology of the body: brachioles, theca, stem and attachment disc. Lateral view.

species are very likely synonyms, and that the differences between $A$. jani and $A$. nuntius can be interpreted as the result of individual variation, ontogeny and taphonomic processes. We agree with the synonymy of these two species. The new material shows that the morphological differences between $A$. jani and A. nuntius are caused by different ontogenetic phases, and new data from this material has helped us to better understand the taxonomic position of the genus among eocrinoids. A third species, A. knizeki Fatka \& Kordule, 1991 is not the topic of this contribution.

This is the first study of eocrinoid material from the Czech Republic that deals with ontogenetic development. Worldwide, only two similar studies have been performed, so our knowledge about eocrinoids ontogeny is still scant. It is very rare to find echinoderm material that encompasses a wide range of developmental phases. This new Akadocrinus material provides critical information that helps us understand morphological changes during growth. Not only could ontogenetic questions be addressed, but the new data also helped to clarify some classification issues, as mentioned above, and describe newly observed morphological details. The primary aim of this paper is to show morphological changes during Akadocrinus ontogenetic development.

\section{Geological setting}

The Jince Formation is a siliciclastic unit dominated by greywacke, claystone and sandstone (Kukal 1971). The formation is less than $100 \mathrm{~m}$ thick in the western part of the basin, and reaches up to $450 \mathrm{~m}$ in the Litavka River Valley (Havlíček 1998, Fatka \& Szabad 2014a). Trilobites and other skeletal fauna of agnostids, echinoderms, hyoliths and brachiopods are generally common throughout the Jince Formation (see Šnajdr 1958, Havlíček 1998, Geyer et al. 2008, Fatka \& Szabad 2014a). Recently, exceptionally well-preserved specimens of Burgess Shale-type fauna have been recognized in the Jince Formation (e.g. Mikulás \& Kordule 1998, Chlupáč \& Kordule 2002, Maletz et al. 2005, Mikuláš et al. 2012, Fatka et al. unpublished data).

A large part of the studied eocrinoid material comes from the collection of the late Vratislav Kordule. This collection was purchased in part by the Czech Geological Survey, Prague and the National Museum, Prague. This echinoderm material was collected from two outcrops in the Jince Formation in the vicinity of the town of Jince: the stratotype section of the Jince Formation above the Litavka River on the south-eastern slope named Vinice (outcrop 1

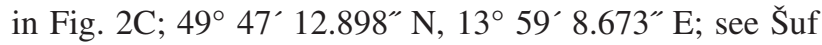
1928, Fatka \& Kordule 1992) and the north-eastern slope of the Vystrkov Hill near Jince (outcrop 2 in Fig. 2C; $49^{\circ} 46^{\prime} 45.922^{\prime \prime} \mathrm{N}, 13^{\circ} 58^{\prime} 2.379^{\prime \prime} \mathrm{E}$ ). In both outcrops, a continuous succession in greywackes to shales of the Paradoxides (P.) paradoxissimus gracilis Trilobite Biozone contains moderately diverse fauna, which includes abundant conocoryphid, ptychoparidand paradoxidid trilobites, agnostids (Peronopsis and Hypagnostus) and hyolithids, all associated with rare bivalved arthropods (Tuzoia, Forfexicaris, Konicekion and Liangshanella), brachiopods, gastropod-like molluscs, diverse problematica, acritarchs and ichnofossils (for a list of taxa see Fatka et al. 2004, Geyer et al. 2008, Fatka \& Szabad 2014a).

Abundant occurrence of the paradoxidid trilobite Paradoxides $(P$.) paradoxissimus gracilis and the agnostid Hypagnostus parvifrons indicates an age corresponding to middle and higher levels of the Baltic Paradoxides (P.) paradoxissimus Biozone (see Weidner \& Nielsen 2013), which is equivalent to the Caesaraugustian Regional Stage in the West Gondwana chronostratigraphic sequence (see Geyer et al. 2008, Gozalo et al. 2011); these levels thus correspond to the Drumian Stage of Cambrian Series 3 (Fatka et al. 2014). 


\section{Material and methods}

The studied specimens are preserved articulated, nearly complete to complete external molds in very fine-grained shale. Excellently preserved material allows detailed study of both external and internal surfaces of thecal walls, but only the external surfaces of brachioles, stems and attachment discs. One to four latex casts were made from all studied specimens. At first, one or two cleaning casts were produced, they cleaned the rock surface from dust and products of weathering (e.g. limonite). Subsequently, one or more new latex casts were made; one of them was coated with ammonium chloride and photographed using an Olympus SZX-12 optical microscope with an Olympus D digital camera. A number of different morphological measurements were made in order to analyse the studied specimens. The following parameters were measured using Quick PHOTO MICRO 3.0.: length of brachioles and brachiolar plate; thecal height, thecal width and thecal plate size; length and width of stem, height of columnal, width, height and diameter of attachment disc, and size of attachment disc plates. Drawings were produced from the photographs using Corel Draw X6 and Adobe Photoshop CS5. All specimens are deposited in collections of the National Museum, Prague (L42222, L42223, L42226, L42227a, L42227b and L42230) and in the Czech Geological Survey, Prague (YA1191, YA1193, YA1195, and YA1197).

\section{Systematic palaeontology}

We used the terminology proposed by Sprinkle (1973) brachioles, stem, attachment disc. However, we prefer to use the term theca instead of calyx (see Ubaghs 1967, Parsley 2012, Zamora et al. 2013).

Subphylum Blastozoa Sprinkle, 1973

Class Eocrinoidea Jaekel, 1918

Order Gogiida Broadhead, 1982

Family Eocrinidae Jaekel, 1918

\section{Genus Akadocrinus Prokop, 1962}

Diagnosis. - (after Sprinkle 1973, pp. 105-106) Eocrinoids having an elongate, flat-topped, irregularly multiplated calyx bearing epispires (sutural pores) medially, numerous biserail brachioles branching off the summit in groups, and a long, large-diameter stem having a few irregularly wedge-shaped columnals proximally, a large diameter lumen, and a rounded, irregularly plated attachment disk at the distal end.

Type species. - Akadocrinus jani Prokop, 1962. Jince For-

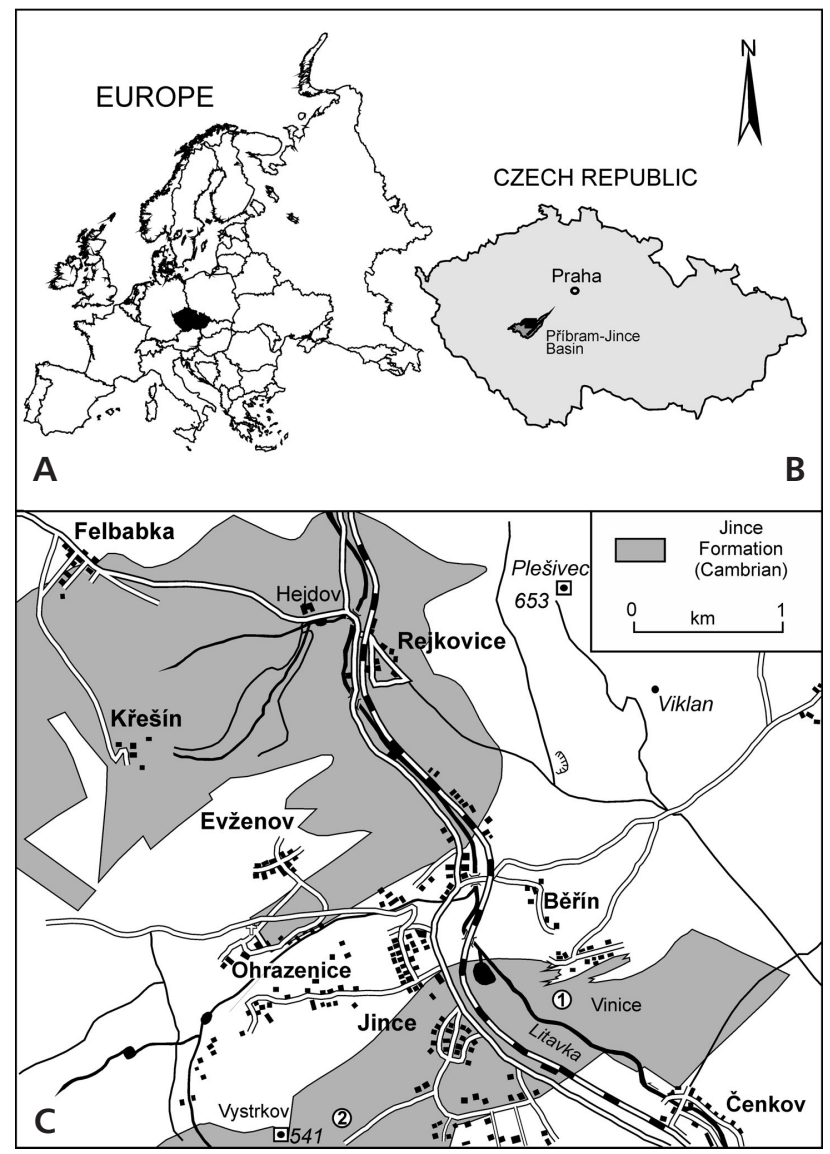

Figure 2. Geological setting. - A - location of the study area in Europe. - B - map of the Czech Republic and the Príbram-Jince Basin. • C - simplified sketch map showing the location of fossil sites in the mid-Cambrian Jince Formation within the Př́bram-Jince Basin (geology modified from Havlíček 1971). 1 - hill slope of Vinice near Jince; 2 - Vystrkov Hill near Jince.

mation, Hypagnostus parvifrons Biozone, Drumian, Př́bram-Jince Basin, Barrandian area, Czech Republic.

\section{Akadocrinus jani Prokop, 1962}

Figures 3-6

1962 Akadocrinus jani (Prokop). - Prokop, pp. 2-4, pl. 1, figs 1,2 .

1967 Akadocrinus jani (Prokop). - Ubaghs, pp. S479-S480, fig. $3072 \mathrm{a}, 2 \mathrm{~b}, 2 \mathrm{c}$.

1973 Akadocrinus jani (Prokop). - Sprinkle, pp. 105-106; 248, pl. 26, figs 1, 2.

1975 Akadocrinus jani (Prokop). - Ubaghs, p. 90, fig. 6D.

2002 Akadocrinus jani (Prokop). - Cid \& Alonso, p. 27.

2002 Akadocrinus jani (Prokop). - Chlupáč \& Kordule, p. 177.

2004 Akadocrinus jani (Prokop). - Parsley \& Prokop, p. 148.

2004 Akadocrinus jani (Prokop). - Fatka et al., p. 379. 


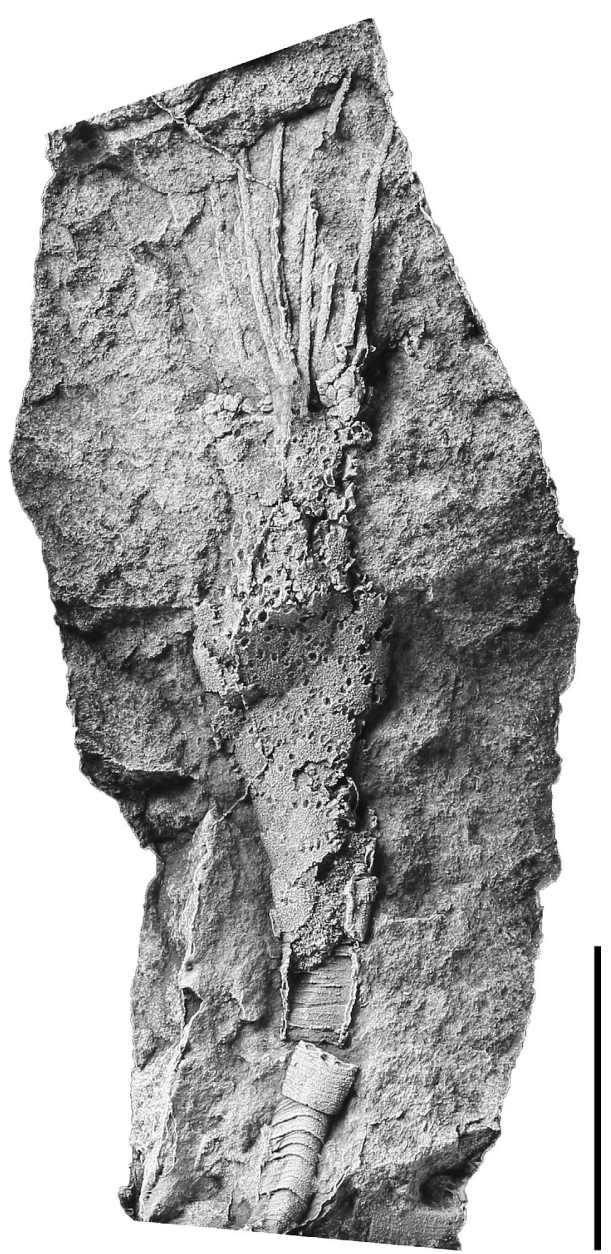

Figure 3. Latex cast of the holotype of Akadocrinus jani Prokop, 1962; mid-Cambrian, Jince Formation, Paradoxides (Paradoxides) paradoxissimus gracilis Zone. Housed in collections of the National Museum Prague under number BR-76/1960, L 8045. Scale bar $=1 \mathrm{~cm}$.

\section{Akadocrinus jani (Prokop). - Clausen \& Smith, p. 746.}

Holotype. - Almost complete specimen housed in the collections of the National Museum Prague under number BR-76/1960, L 8045 (see Fig. 3).

Diagnosis (emended). - Theca elongate, barrel-shaped, composed of polygonal plates (often irregularly pentagonal and hexagonal plates). Theca narrowing to both aboral and adoral ends. Polygonal plates of varying size, on external surface fine granulation. Internal surface smooth. Smaller plates situated in oral part of theca, usually irregularly arranged. Minute plates intercalated between larger plates in all parts of theca. Between thecal plates, oval epispires with well-distinguishable raised rims. Numerous long and thin brachioles, with biserial structure, simple, never branched. Base of theca grades into stem composed of equally sized, low columnals. Stem long, distally narrowing. Stem with comparatively large ovoid disc, composed of varying number of polygonal plates.

Remarks. - The original diagnosis was established by Prokop (1962). Additional material of this species has been found since then, and shows previously unknown characters. Consequently an emended diagnosis is proposed.

\section{General morphological description of studied material}

Ten specimens were used for this study; eight nearly complete and two less so.

In this section that is focused on a detailed morphological description of the studied specimens we decided to divide the material into two main groups, based on differences in morphology. Our principal interest was in juvenile specimens, which have not yet been studied. This previously undescribed material yields new information about morphology of this group of early echinoderms. The connection with ontogenetic development is discussed below.

\section{Juvenile specimens (Figs 4-6)}

This material has been never studied before, and small specimens of Akadocrinus were not known. The excellent preservation of this material allowed observation of new morphological details, and comparison of juvenile against adult specimens. These data are important to properly understand the ontogeny of this eocrinoid species.

Brachioles. - All brachioles show a biserial structure. In juveniles specimens, quite short brachioles (maximal length of preserved brachioles is $2.09 \mathrm{~mm}$ ) are composed of a variable number of brachiolar plates, which usually measure from 0.08 to $0.44 \mathrm{~mm}$. Juvenile specimens of Akadocrinus generally have two to four brachioles.

Theca. - Juvenile specimens generally show a common outline of theca, elongated and barrel-shaped. In juvenile

Figure 4. Early ontogenetic specimens of Akadocrinus jani Prokop, 1962; mid-Cambrian, Jince Formation, Paradoxides (Paradoxides) paradoxissimus gracilis Zone. Three specimens with the smallest thecal dimension. Specimens YA1191 and YA1193 housed in the Czech Geological Survey, Prague, specimen L42227b stored in the collection of the National Museum in Prague. • A - slightly damaged complete specimen. Latex cast of 

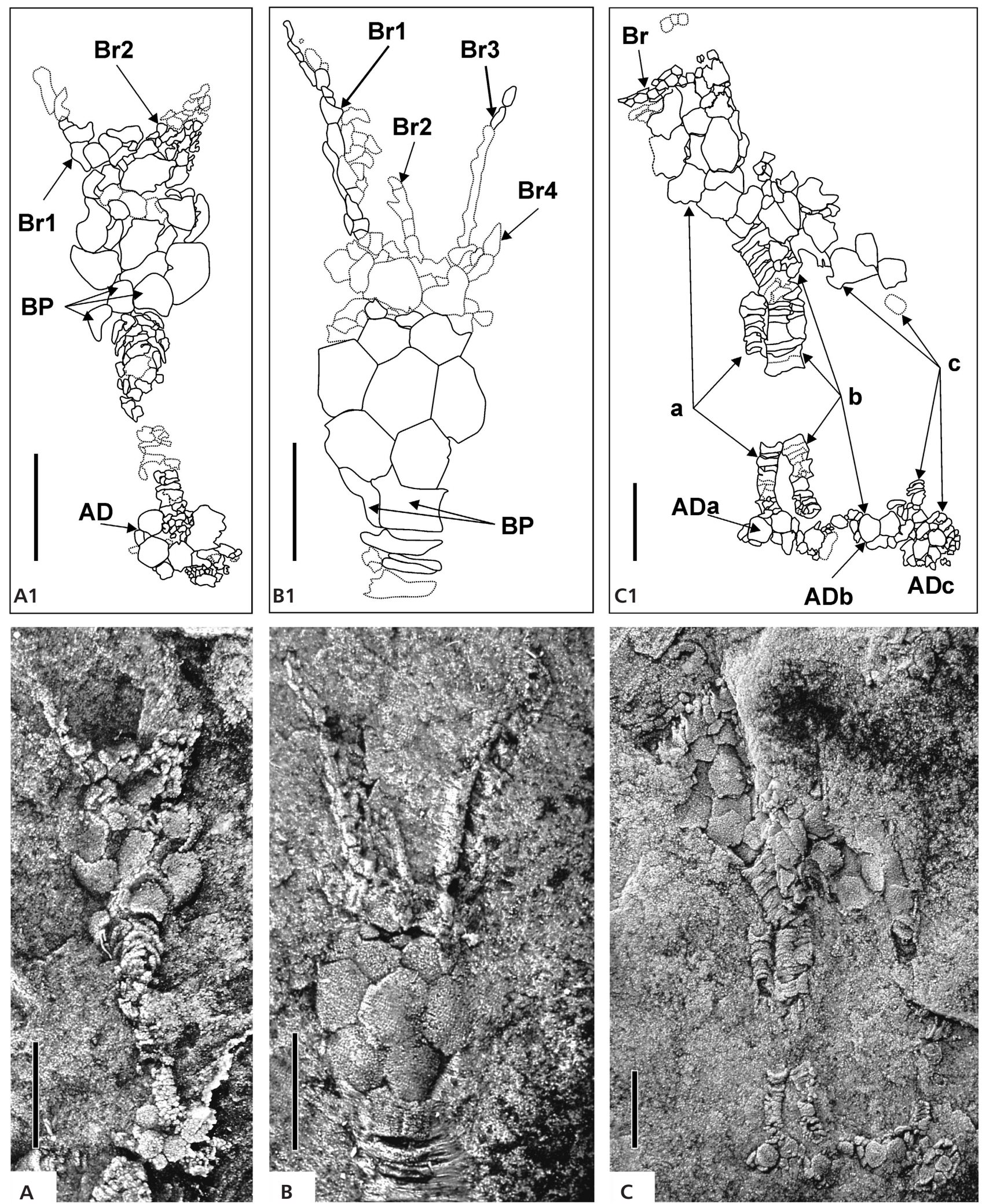

YA1191, Vystrkov Hill near Jince near Jince, TH $=1.74 \mathrm{~mm}$. $\bullet$ B - theca with proximal part of stem and partly preserved brachioles. Latex cast of YA1193, Vystrkov Hill near Jince, TH $=1.84 \mathrm{~mm} . \bullet \mathrm{C}$ - three slightly damaged specimens (designated as a, b and c). Latex cast of L42227b, hill slope of Vinice near Jince, TH = $2.01 \mathrm{~mm}$. A1, B1, C1 - drawing of specimens made in CorelDrawX6. AD - attachment disc. Br1 to Br4 - brachioles. All scale bars represent $1 \mathrm{~mm}$. All latex casts of natural external molds are coated with ammonium chloride. 
Table 1. Table showing important morphological parameters, which were measured on studied material. All measured parameters are in mm.

\begin{tabular}{|c|c|c|c|c|c|c|c|c|}
\hline \multirow[t]{2}{*}{ specimen } & \multirow{2}{*}{$\mathrm{TH}$} & \multirow{2}{*}{$\begin{array}{c}\text { number } \\
\text { of thecal plates }\end{array}$} & \multicolumn{2}{|c|}{ size of thecal plates } & \multirow{2}{*}{$\begin{array}{c}\text { number } \\
\text { of brachioles }\end{array}$} & \multirow{2}{*}{$\begin{array}{l}\text { max length } \\
\text { of brachioles }\end{array}$} & \multirow{2}{*}{ length of stem } & \multirow{2}{*}{$\begin{array}{c}\text { diametre } \\
\text { of attachment disc }\end{array}$} \\
\hline & & & $\min$ & $\max$ & & & & \\
\hline YA1191 & 1.74 & 40 & 0.17 & 0.60 & 2 & 1.04 & 2.18 & $1.07 \times 0.41$ \\
\hline YA1193 & 1.84 & 30 & 0.08 & 0.69 & 4 & 2.09 & 1.30 & - \\
\hline L42227b & 2.01 & 25 & 0.10 & 0.55 & - & - & 3.53 & $1.00 \times 0.46$ \\
\hline YA1195 & 2.02 & 10 & 0.22 & 0.57 & 2 & 1.41 & 2.89 & $1.09 \times 0.68$ \\
\hline YA1197 & 2.14 & 7 & 0.28 & 0.97 & 3 & 0.90 & 2.24 & - \\
\hline L42230 & 2.19 & 30 & 0.11 & 0.70 & 3 & 2.00 & 4.18 & $1.42 \times 0.7$ \\
\hline L42227a & 2.70 & 36 & 0.20 & 0.60 & 3 & 1.60 & 3.75 & $1.37 \times 0.50$ \\
\hline
\end{tabular}

specimens, thecal height varies from 1.74 to $2.7 \mathrm{~mm}$. The number of thecal plates is usually less than 50 . It can be supposed that thecal plates were arranged in several more or less regular circlets. However, some of the studied specimens show more or less apparent distortions of this arrangement. The lowest number of preserved thecal plates is seven, in specimen YA1197 (Fig. 5B). Thecal plates of different size are roughly tetragonal to hexagonal in outline. The average size of thecal plates ranges around $0.40 \mathrm{~mm}$ in juvenile specimens. Plates situated in the radial part of the theca are larger than in the oral part. Their external surface bears fine granulation.

Epispires. - Juvenile specimens have no epispires; this was in fact the criterion we used to separate the specimens into juvenile and adult groups.

Stem. - The stem is composed of columnals of quite uniform height, about $0.06 \mathrm{~mm}$, wider proximally, narrower distally. The length of the stem is variable, ranging from 1.30 (incomplete stem, Fig. 4B1) to $4.18 \mathrm{~mm}$ (Fig. 5C). In complete specimens, the stem is terminated by a distal attachment disc (Fig. 6).

Attachment disc. - The attachment disc quite large, ovoid in outline, composed of plates of various sizes.

\section{Mature specimens (Fig. 7)}

Here we present three excellently preserved specimen of Akadocrinus jani. The exceptional quality of preservation shows rare details, which have never before been obser- ved in this eocrinoid echinoderm. For the first time, we were able to observe internal surfaces of thecal plates and ambulacral furrows in specimens from the Barrandian area.

Brachioles. - Biserial brachioles quite long (maximum length of preserved brachioles is $20.00 \mathrm{~mm}$ ), composed of variable number of brachiolar plates, usually from 0.17 to $0.82 \mathrm{~mm}$. Number of brachiolar plates is several times higher than in juveniles. Number of preserved brachioles varies, usually from 7 to 14. Specimen L42226 (Fig.7C) has preserved ambulacral furrow.

Theca. - Elongate, barrel-shape, distally narrowing. Adult specimens always have more than 50 plates in theca, often around 100. Adults also usually have more irregularly shaped thecal plates. Average size of thecal plates around $0.99 \mathrm{~mm}$ in adults. Smallest plates are $0.21 \mathrm{~mm}$ high, largest around $1.69 \mathrm{~mm}$. Thecal height more than $10 \mathrm{~mm}$.

Minimally three generations of plates in theca, of differing sizes. In most cases, developmentally older plates are larger than younger one. New plates are intercalated between older plates. Sometimes new small plates make a ring, called rosette, around older plates. Intercalation of new plates disrupts the circlet plate order observed in juvenile stages. External surface of thecal plates bears fine granulation, internal surface smooth (Fig. 7B).

Epispires. - Adult specimens (thecal height greater than $10 \mathrm{~mm}$ ) bear ellipsoidal epispires with clearly visible rim (Fig. 8B). Number of epispires corresponds with size of thecal plates. Small plates show a low number of epispires, larger plates more than ten.

Figure 5. Early ontogenetic specimens of Akadocrinus jani Prokop, 1962; mid-Cambrian, Jince Formation, Paradoxides (Paradoxides) paradoxissimus gracilis Zone. Specimens YA1195 and YA1197 housed in the Czech Geological Survey, Prague, specimen L42230 stored in the collection of the National Museum in Prague. • A - two nearly complete severely damaged specimens (designated as a and b). Latex cast of YA1195, Vystrkov Hill near Jince, $\mathrm{TH}=2.02 \mathrm{~mm}$. $\bullet \mathrm{B}$ - partly preserved specimen with four poorly-preserved brachioles. Latex cast of YA1197, Vystrkov Hill near Jince, $\mathrm{TH}=2.14 \mathrm{~mm} . \cdot \mathrm{C}-$ complete specimen with three brachioles. Latex cast of L42230, locality unknown, TH = 2.19 mm. A1, B1, C1- drawing of specimens made in CorelDrawX6. Br1 to Br4 - brachioles. BrPl - brachiolar plates. All scale bars represent 1 mm. All latex casts of natural external molds are coated with ammonium chloride. 
Martina Nohejlová \& Oldřich Fatka • Cambrian eocrinoid Akadocrinus
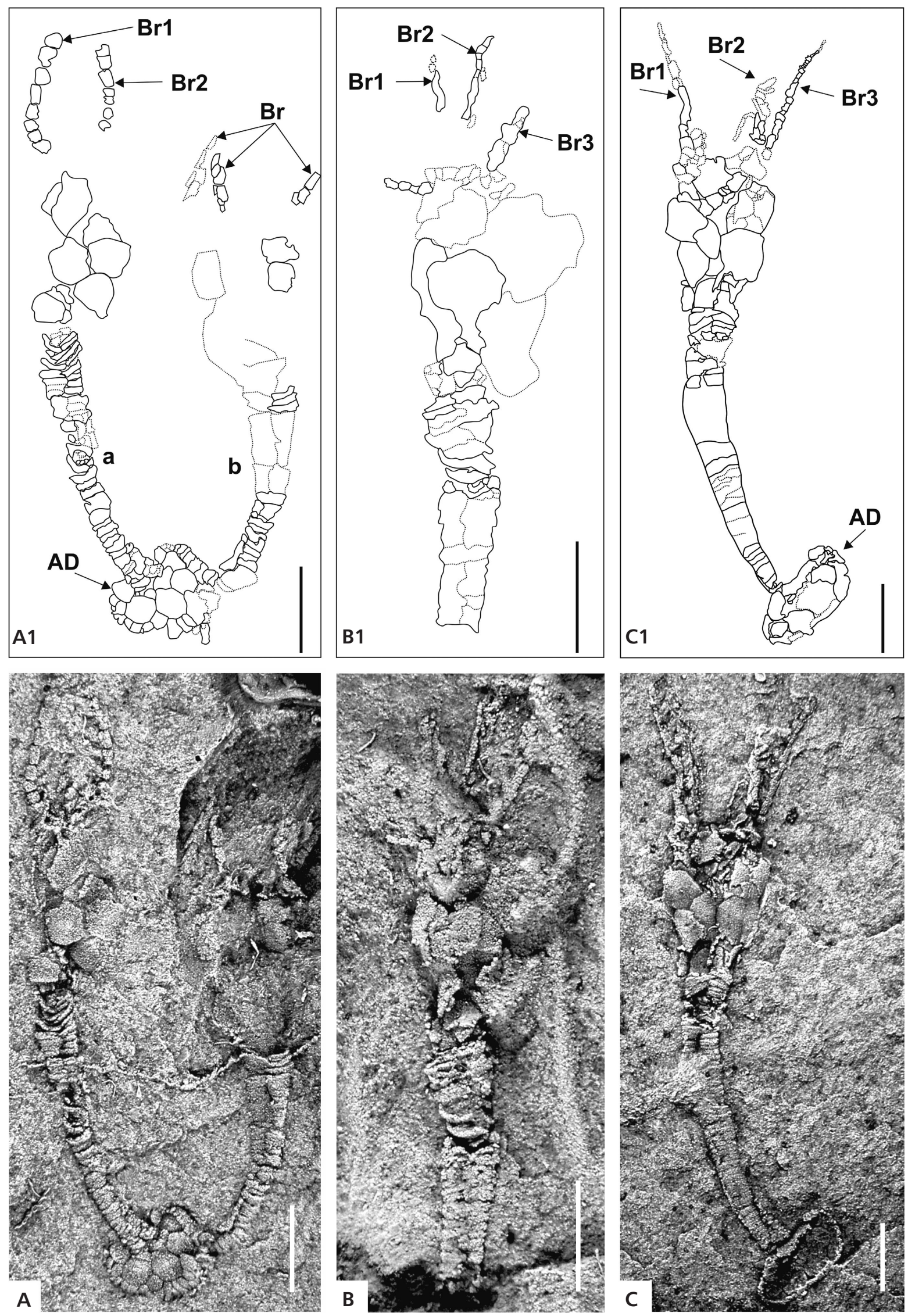

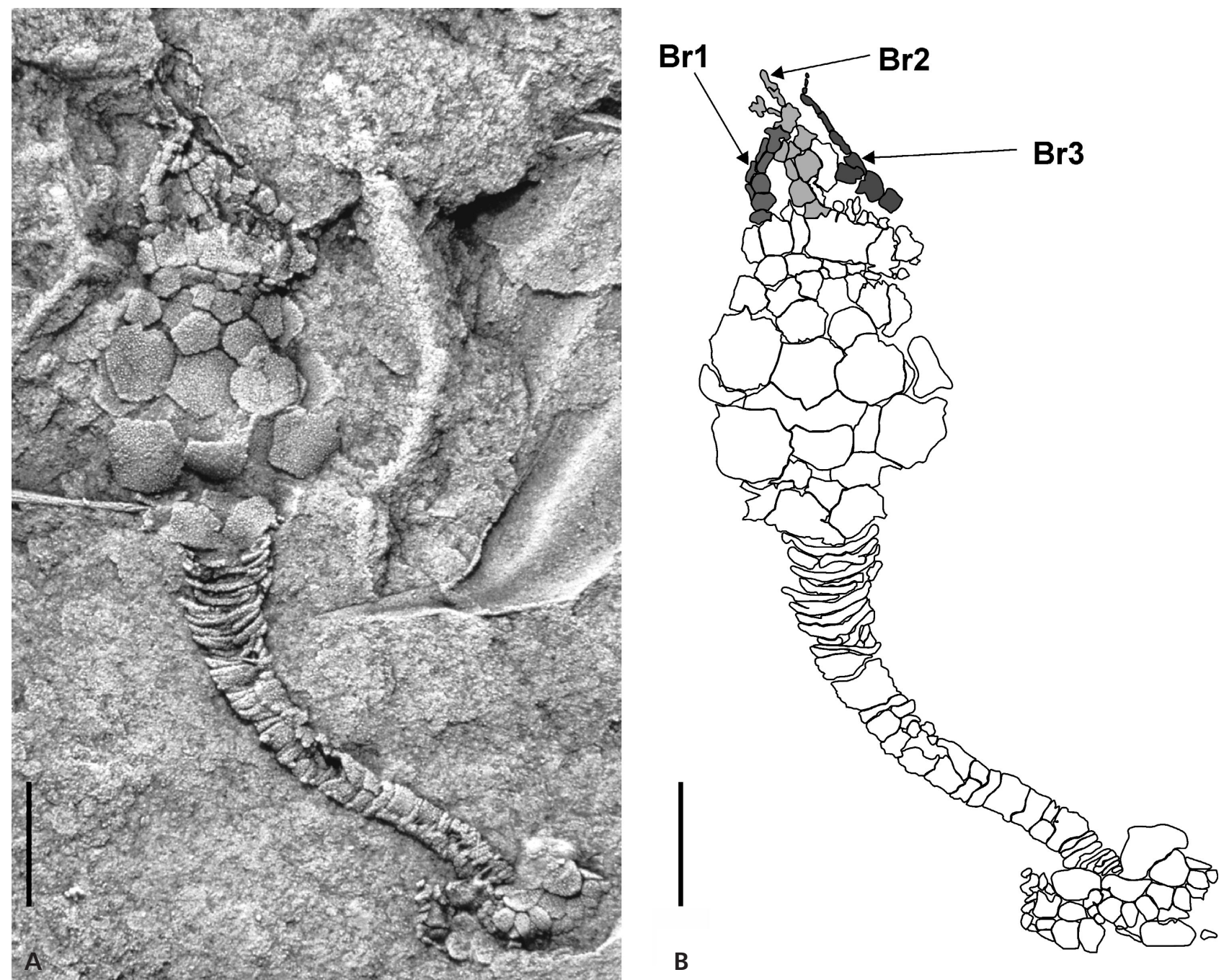

Figure 6. Early ontogenetic specimen of Akadocrinus jani Prokop, 1962; mid-Cambrian, Jince Formation, Paradoxides (Paradoxides) paradoxissimus gracilis Zone. The specimen is stored in the collection of the National Museum in Prague. • A - complete specimen with three brachioles. Latex cast of L42227a, hill slope of Vinice near Jince, TH $=2.7 \mathrm{~mm}$. B - drawing of specimen L42227a made in CorelDrawX6. Br1 to Br3 - brachioles. Scale bar represents $1 \mathrm{~mm}$. Latex cast of natural external molds is coated with ammonium chloride.

Stem. - Stem composed of columnals, quite uniform height. Normal size of columnal about $0.06 \mathrm{~mm}$. Stem wider proximally, narrower distally. Length of stem variable, usually more than $20 \mathrm{~mm}$ long on studied specimens. We do not have a complete preserved stem.

Attachment disc. - Not preserved in studied specimens.

\section{Discussion}

\section{Ontogeny of eocrinoids}

It is generally rare to describe complete ontogenetic development in fossil echinoderms. Currently, the ontogeny of eocrinoids echinoderms is poorly understood, since well-preserved material is extremely rare. Only a few studies have been done with gogiids echinoderms; Parsley \& Zhao (2006) and Parsley (2012) described specimens originating from the early and mid-Cambrian of South China, and Zamora et al. (2013) discussed North American materials. In the first two papers, an informal classification of ontogenetic development of Gogia was proposed. Parsley (2012) distinguished several ontogenetic stages using thecal height $(\mathrm{TH}=$ the distance from the summit of the theca to the top of the stalk) as a scale, complemented by five identifying characters that are important for ontogeny. Based on three Chinese species, Guizhocrinus yui, Sinoeocrinus lui and Globoeocrinus globulus, a complete ontogenetic sequence was established with three different stages: (a) juvenile stage (with early, middle and late substages); (b) mature stage (early, middle and late substa- 

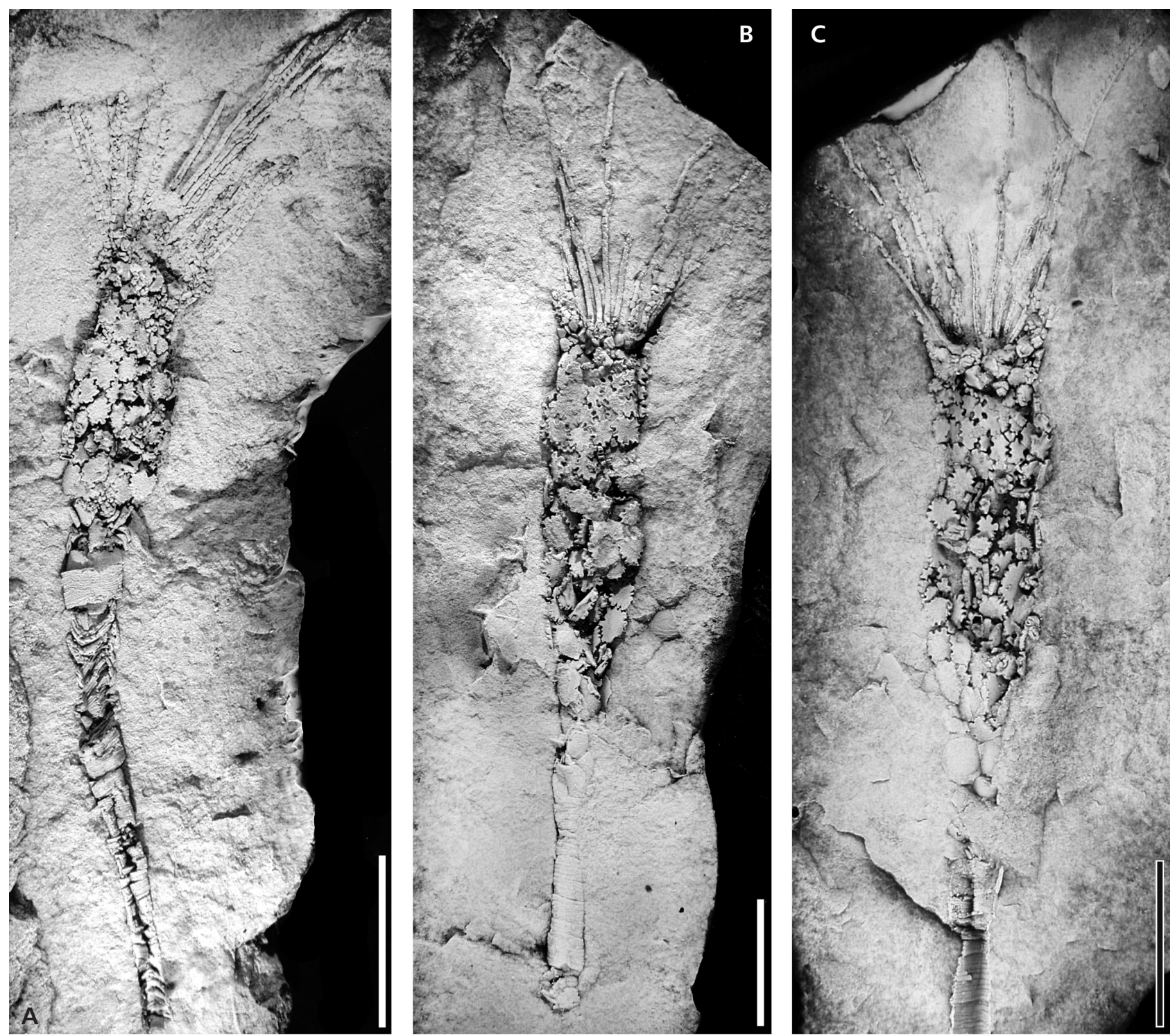

Figure 7. Late ontogenetic specimens of Akadocrinus jani Prokop, 1962; mid-Cambrian, Jince Formation, Paradoxides (Paradoxides) paradoxissimus gracilis Zone. The specimens are deposited in the collections of the National Museum in Prague. • A - almost complete specimen without attachment disc, latex cast of L42222, hill slope of Vinice near Jince, TH $=18.39 \mathrm{~mm}$. B - almost complete specimen, without attachment disc, latex cast of L42223, $\mathrm{TH}=33.93 \mathrm{~mm}$, locality unknown. $\bullet \mathrm{C}-$ almost complete specimen, without attachment disc, latex cast of L42226, hill slope of Vinice near Jince, $\mathrm{TH}=34.21 \mathrm{~mm}$. Scale bar $1 \mathrm{~cm}$. Latex cast of natural external molds is coated with ammonium chloride.

ges), and (c) gerontic stage. The five important characters are: (1) number and morphology of brachioles; (2) the number of thecal plates and their arrangement; (3) the number, order, and morphology of epispires; (4) development of the stalk (= stem), and (5) morphology of the distal attachment structure.

Zamora et al. (2013) showed that all studied specimens of Gogia sp. have TH spanning a size interval that encompasses all the stages that Parsley (2012) distinguished in the Chinese material. This important study of Gogia sp., in which Zamora et al. (2013) statistically analyzed a large amount of material, showed that post-meta- morphic development most probably represents a continuous process. There are no statistical support for any of the size groupings separated previously by Parsley \& Zhao (2006) and Parsley (2012). We agree with the opinion that a separation of distinct ontogenetic stages based only on $\mathrm{TH}$ represents an artificial classification (Zamora et al. 2013). On the basis of additional, newly analyzed material, we suspect that $\mathrm{TH}$ is insufficient to completely distinguish the three stages, although the limited number of specimens and partial knowledge of the complete population of the Jince material somewhat restricts our analyses. 

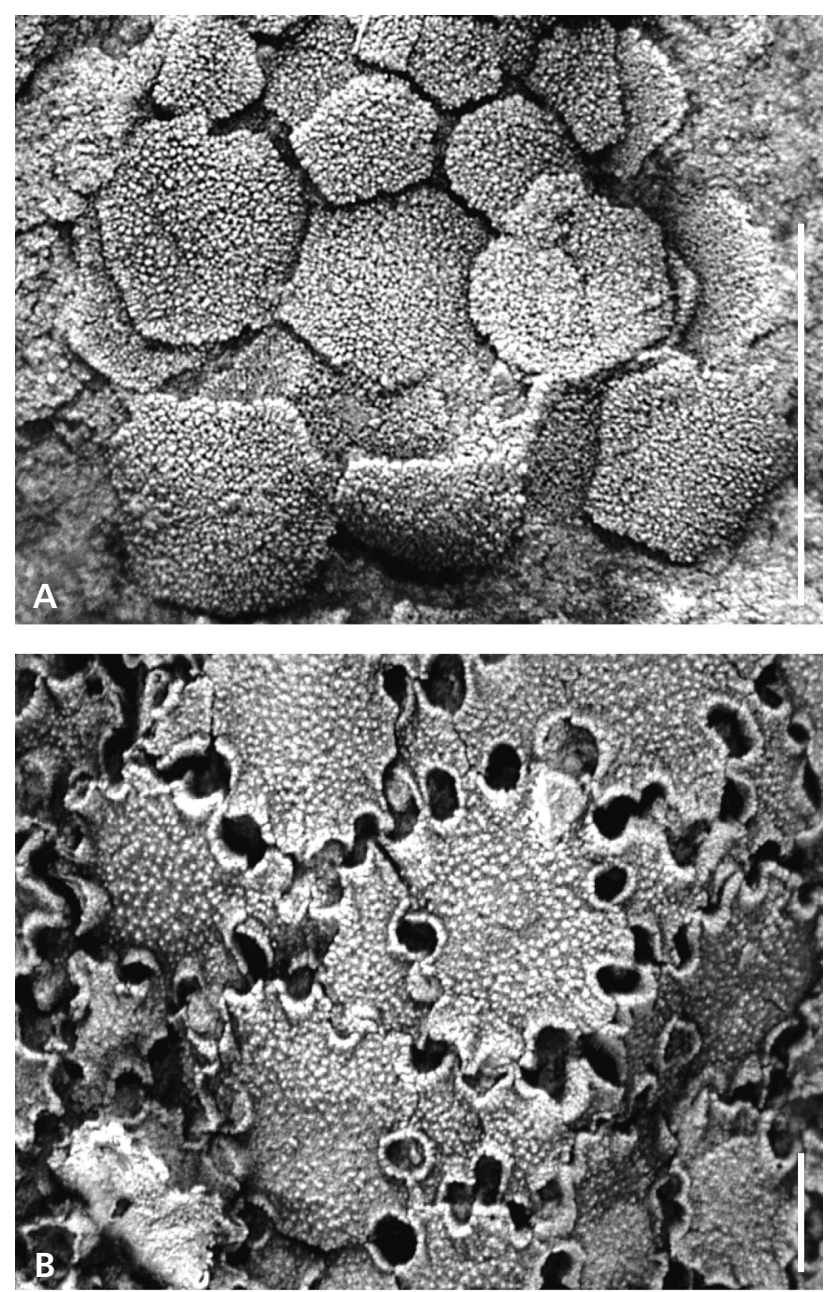

Figure 8. Detail of thecal plates. There are clearly visible differences between plates of pre-epispire bearing phase specimen and epispire bearing phase specimen. • A - Akadocrinus jani Prokop, 1962; latex cast of specimen L42227a, hill slope of Vinice near Jince. Juvenile specimen with quite regular thecal plates and no evidence of epispires. $\bullet \mathrm{B}-\mathrm{Aka}$ docrinus jani Prokop, 1962; latex cast of specimen L42228, locality unknown. Mature specimen has irregular shape of thecal plates with epispires boundered by clearly visible rims. Scale bar represents $1 \mathrm{~mm}$. Both latex casts of natural external molds are coated with ammonium chloride.

\section{Ontogenetic development of Akadocrinus jani}

Morphological characterization of the studied material was described in an earlier part of this paper and we are confident that data from our material shows differences in morphology during the ontogenetic development. The juvenile specimens of Akadocrinus jani have different morphology from adult specimens. It is possible to document the following changes during ontogeny:

(i) increasing number and prolongation of brachioles,

(ii) increasing thecal height,

(iii) increasing number of enlarging thecal plates,

(iv) prolongation of stem.
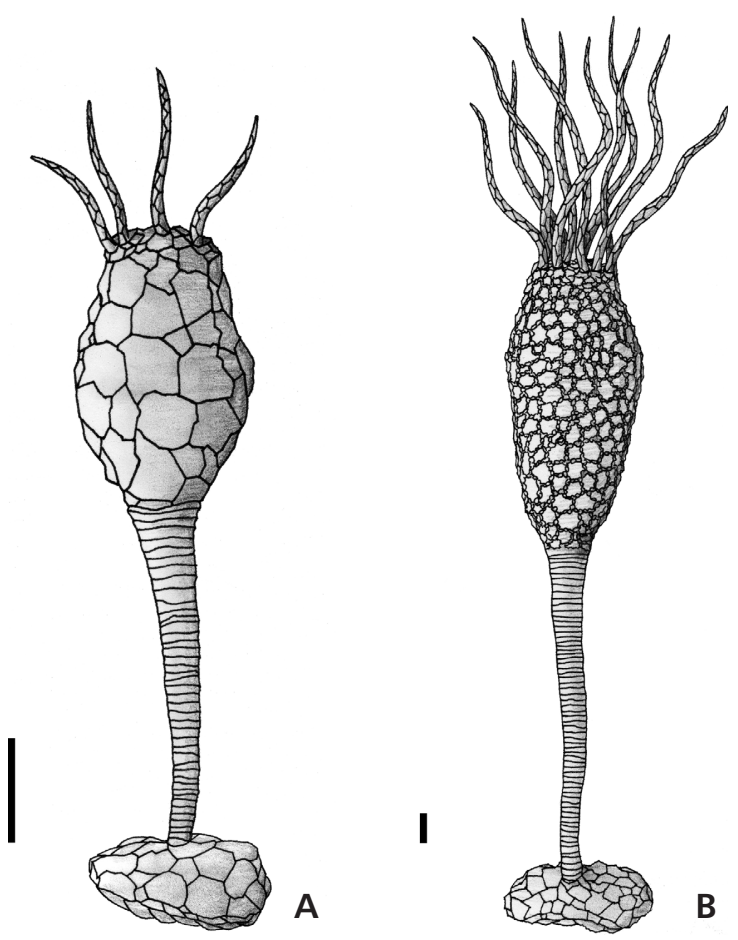

Figure 9. A - pre-epispire bearing phase - Akadocrinus. $\bullet \mathrm{B}$ - epispire bearing phase -Akadocrinus. Both scale bars represent $1 \mathrm{~mm}$.

When we compare the number of brachioles in juvenile and adult specimens, we see a clear difference in the number. Smaller specimens usually have 2-4 brachioles, older ones 7-14. Also, the length of brachioles and thecal height both increase during ontogeny. The smallest specimen has $\mathrm{TH}=1.74 \mathrm{~mm}$ (specimen YA1191, Fig. 4A), the largest $34.21 \mathrm{~mm}$ (specimen L 42226, see Fig. 7C). The number of thecal plates increases, as well as their size. Juvenile Akadocrinus have less than 50 thecal plates, with average size around $0.40 \mathrm{~mm}$, as opposed to adult specimens, which have more than 100 thecal plates, with average size around $0.99 \mathrm{~mm}$. During ontogenetic development, the theca grows by two basic mechanisms: (1) increasing size of primary plates, and (2) intercalation of new small secondary plates between the older plates. This mechanism is known also from other eocrinoids. It is usually possible to distinguish three generations of thecal plates in adult specimens. No epispire has been observed in studied juvenile specimens. In comparison, adult specimens bear ellipsoidal epispires, with a clearly visible rim (Fig. 8). The number of epispires correlates with the size of thecal plates. Small plates show a low number of epispires, while larger plates bear more than ten epispires. The length of stem increases with age; juveniles have maximal stem length $4.18 \mathrm{~mm}$. Adults present a small problem, in that we do not have a single preserved complete stem. Even so, we know from fragments that we do have, that the length of stem is markedly longer, usually more than $20 \mathrm{~mm}$. Most juvenile 
Table 2. Table showing comparison of thecal heights of Czech and Chinese material typical for each ontogenetic stage. For measurement were used nineteen specimens of Akadocrinus jani Prokop, 1962 deposited in collection of the Czech Geological Survey and the National Museum in Prague. Used Chinese data after Parsley (2012). All thecal heights were measured in millimeters.

\begin{tabular}{lcc}
\hline & Czech material & Chinese material \\
\hline juvenile stage & $\mathrm{TH} \geq 1,74$ & $\mathrm{TH} \geq 1,4$ \\
mature stage & $\mathrm{TH}>10$ & $\mathrm{TH}>8$ \\
gerontic stage & $\mathrm{TH}>25$ & $\mathrm{TH}>22$ \\
\hline
\end{tabular}

specimens have a preserved attachment disc, but in our material, there is no adult specimen with an attachment disc.

Ontogenetic development is a continual process, with no strict boundaries separating different stages. Based on the above-mentioned morphological changes, we suggest distinguishing only two major phases in ontogenetic development of Akadocrinus. The main difference between these two ontogenetic phases is in the presence/absence of epispires (Fig. 8), although other, less significant morphological changes also occur during the transition between phases. We propose the following dividing into:

I. Pre-epispire bearing phase.-Specimens belonging to this phase show no evidence of epispires, between thecal plates or on the external surface of thecal plates. All described juvenile specimens are included in this phase of the ontogeny.

II. Epispire bearing phase. - Specimens show well developed epispires, both with and without a visible rim. All adult specimens described here belong to this phase.

We prefer to distinguish these two phases, rather than division into juvenile, adult and gerontic stage. Epispires are for us the most significant developmental character, because they indicate a marked change in the respiratory mechanism. Epispires are the most primitive respiratory structures in echinoderms (Parsley 2013). During the first phase of ontogeny, specimens were able to respire without epispires.

It is not yet possible to determine a thecal height above which Akadocrinus starts to have epispires. All small specimens are without epispires, and all large ones already have epispires. There is no specimen corresponding to the transitional stage between the pre-epispire bearing and epispire bearing phase. We consider it likely that epispires started to appear at the oral part of theca, then later in the other parts of theca, as has been described in other eocrinoids (Parsley 2013, Parsley \& Prokop 2014). Juvenile specimens - the pre-epispire bearing specimens - have maximum thecal height not more than $3 \mathrm{~mm}$. Adult specimens - of the epispire bearing phase - have thecal height more than $10 \mathrm{~mm}$. Epispires begin to appear somewhere in the interval of $\mathrm{TH}=3-10 \mathrm{~mm}$.

Based on thecal height in Akadocrinus it could be possible to follow the approach of Parsley (2012) in separation of three informal ontogenetic stages in the studied material from the Barrandian area.

As shown in Table 2, specimens from the Barrandian area reach larger dimension in each stage when compared with Chinese material. However, we have not observed any difference in development between the mature and gerontic stages.

\section{Conclusions}

Akadocrinus is the first Cambrian eocrinoid from West Gondwana in which ontogenetic development is documented. The excellently preserved juvenile specimens show clear morphological differences from adult specimens. The juvenile specimens are characterized by the following morphology: (1) a lower number of thecal plates, (2) a complete absence of epispires, (3) comparatively shorter brachioles, composed of a lower number of brachiolar plates, (4) comparatively shorter stem, comprising lower number of columnals, and (5) relatively large attachment disc. The main ontogenetic changes are seen in thecal morphology. It is possible to distinguish two basic phases of development; (A) the pre-epispire bearing phase (thecal plates without epispires) and (B) epispire bearing phase (thecal plates with epispires).

\section{Acknowledgements}

This research was supported by the GA UK (Grant Agency of Charles University) No. 776213 "Ontogeny of class Eocrinoidea" and the project PRVOUK P44 of the Ministry of Education, Youth and Sports of the Czech Republic. The authors would like to thank Jan Karel for graphic assistance, and Peter Daneš for assistance with English. The reviewers, Samuel Zamora (Zaragoza, Spain) and Ronald L. Parsley (New Orleans, U.S.A), as well as the handling editor are greatly acknowledged for their insightful and critical comments.

\section{References}

BARRANDE, J. 1846. Notice préliminaire sur le Systême silurien et les Trilobites de Bohême. 97 pp. Hirschfeld, Leipzig.

BARRANDE, J. 1887. Systême silurien du centre de la Bohême. Volume VII. Classe des Echinodermes, Ordre des Cystidées. 233 pp. Praha \& Leipzig.

BroAdHEAD, T.W. 1982. Reappraisal of Class Eocrinoidea (Echinodermata), 125-131. In LAwrence, J.M. (ed.) International Echinoderms Conference, Tampa Bay. Balkema, Rotterdam.

Chlupáč, I. \& Kordule, V. 2002. Arthropods of Burgess Shale type from the Middle Cambrian of Bohemia (Czech Republic). Bulletin of Geosciences 77(3), 167-182. 
CiD, M.D.G. \& Alonso, P.D. 2002. Ubaghsicystis segurae nov. gen. y sp., nuevo Eocrinoide (Echinodermata) del Cámbrioco Medio del Norte de España. Coloquios de Paleontología 53, 21-32.

Clausen, S. \& Smith, A.B. 2008. Stem structure and evolution in the earliest pelmatozoan echinoderms. Journal of Paleontology 82(4), 737-748. DOI 10.1666/06-067.1

Durham, J.W. 1978. A Lower Cambrian eocrinoid. Journal of Paleontology 52(1), 195-199.

FATKA, O. 2011. Cambrian of the Barrandian area and the International Subcommission on Cambrian stratigraphy. Bulletin of Geosciences 86(3), 387-390. DOI 103140/bull.geosci.1322

FAtKa, O. \& Kordule, V. 1990. Vyscystis ubaghsi gen. et sp. nov., imbricate eocrinoid from Czechoslovakia (Echinodermata, Mid-Cambrian). Věstník Ústředního ústavu geologického 59(5), 299-302.

FAtKa, O. \& Kordule, V. 1991. Akadocrinus knizeki sp. nov., gogiid eocrinoid from Czechoslovakia (Echinodermata, Mid-Cambrian). Věstník Českého geologického ústavu 66(4), 239-244.

FatKa, O. \& Kordule, V. 1992. New fossil sites in the Jince Formation (Mid-Cambrian, Bohemia). Věstník Českého geologického ústavu 67(1), 47-60.

FAtKa, O., Kordule, V. \& Szabad, M. 2004. Stratigraphic distribution of Cambrian fossils in the Př́bram-Jince Basin (Barrandian area, Czech Republic). Senckenbergiana lethaea 84(1/2), 369-384.

FATKA, O. \& SzABAD, M. 2014a. Biostratigraphy of Cambrian in the Př́ibram-Jince Basin (Barrandian area, Czech Republic). Bulletin of Geosciences 89(2), 413-429. DOI 103140/bull.geosci.1456

FAtKa, O. \& SzABAD, M. 2014b. Family Dibrachicystidae from the "middle" Cambrian of the Barrandian area (Rhombifera, Echinodermata, Czech Republic). Paläontologische Zeitschrift 88(2), 159-166. DOI 10.1007/s12542-013-0193-1

FAtKa, O., Williams, M. \& Budil, P. 2014. Bradoriid arthropods from the Cambrian of the Prríbram-Jince Basin, Czech Republic. Neues Jahrbuch für Geologie und Paläontologie, Abhandlungen 273(2), 147-154. DOI 10.1127/0077-7749/2014/0420

Geyer, G., Elicki, O., Fatka, O. \& Zylińska, A. 2008. Cambrian, 155-202. In McCANN, T. (ed.) Geology of Central Europe. Geological Society of London, London.

Gozalo, R., Chirivella Martorell, J.B., Esteve, J. \& Liñan, E. 2011. Correlation between the base of Drumian Stage and the base of middle Caesaraugustan Stage in the Iberian Chains (NE Spain). Bulletin of Geosciences 86(3), 545-554. DOI 103140/bull.geosci.1254

HAVLíčEK, V. 1971. Stratigraphy of the Cambrian of Central Bohemia. Sborník geologických věd, Geologie 20, 7-52.

HavlíčEK, V. 1998. Cambrian, 20-38. In Chlupáč, I., HavlíčEK, V., KŘiž, J., Kukal, Z. \& Štorch, P. Palaeozoic of the Barrandian (Cambrian to Devonian). Czech Geological Survey, Prague.

Hu, S.X. \& Luo, H.L. 2008. Echinodermata, 102-104, 133. In Luo, H.L., Li, Y., Hu, S., Fu, X., Hou, S., Liu, X., Chen, L., Li, F., PAng, J. \& Liu, Q. (eds) Early Cambrian Malong Fauna and Guanshan Fauna, from Eastern Yunnan, China. Yunnan
Science and Technology Press, Kunming. [in Chinese with English summary]

Hu, S.X., Luo, H.L., Hou, S.G. \& Erdtmann, B.D. 2007. Eocrinoid echinoderms from the Lower Cambrian Guanshan Fauna in Wuding, Yunnan, China. Chinese Science Bulletin 52(5), 717-719. DOI 10.1007/s11434-007-0083-6

JAEKeL, O. 1918. Phylogenie und System der Pelmatozoen. Paläontologische Zeitschrift 3, 1-128. DOI 10.1007/BF03190413

Jell, P.A., Burrett, C.F. \& Banks, M.R. 1985. Cambrian and Ordovician echinoderms from eastern Australia. Alcheringa 9(3), 183-208. DOI 10.1080/03115518508618967

KuKAL, Z. 1971. Sedimentology of Cambrian deposits of the Barrandian area (Central Bohemia). Sborník geologických věd, Geologie 20, 53-100.

Lefebvre, B. \& FatKA, O. 2003. Palaeogeographical and palaeoecological aspects of the Cambro-Ordovician radiation of echinoderms in Gondwanan Africa and peri-Gondwanan Europe. Palaeogeography, Palaeoclimatology, Palaeoecology 195, 73-97. DOI 10.1016/S0031-0182(03)00303-1

Lefebvre, B., Nardin, E. \& FatKa, O. 2015. Body wall homologies in basal blastozoans, 87-93. In ZAMORA, S. \& RÁBANO, I. (eds) Progress in Echinoderm Palaeobiology. Cuadernos del Museo Geominero 19.

Maletz, J., Steiner, M. \& FAtKa, O. 2005. Middle Cambrian pterobranchs and the Question: What is a graptolite. Lethaia 38(1), 73-85. DOI 10.1080/00241160510013204

Mikuláš, R., Fatka, O. \& Szabad, M. 2012. Paleoecologic implications of ichnofossils associated with slightly skeletonized body fossils, mid-Cambrian of the Barrandian area, Czech Republic. Ichnos 19(4), 199-210.

DOI 10.1080/10420940.2012.703626

Mikuláš, R. \& Kordule, V. 1998. A problematic fossil from the Middle Cambrian of the Barrandian area (Czech Republic). Journal of the Czech Geological Society 43(3), 187-190.

NARDin, E. \& LeFEBVRE, B. 2005. Earliest eocrinoids in the western Anti-Atlas (Morocco): implications about their palaeogeography and their relationships. Abstract Book, Climatic and Evolutionary Controls on Palaeozoic Reefs and Bioaccumulations, 7-9 September 2005, 45-46. MNHN, Paris.

Nardin, E., Lefebvre, B., David, B. \& Moi, R. 2009. La radiation des échinodermes au Paléozoïque inférieur, l'exemple des blastozoaires. Comptes Rendus Palevol 8(2-3), 179-188. DOI 10.1016/j.crpv.2008.09.004

NoheJlová, M. \& FATKA, O. 2015. Blastozoan echinoderms from the Cambrian of the Barrandian area (Czech Republic), 119-123. In ZAMORA, S. \& RÁBAno, I. (eds) Progress in Echinoderm Palaeobiology. Cuadernos del Museo Geominero 19.

PARSLEY, R.L. 2009. Morphology, ontogeny, and heterochrony in Lower and Mid-Cambrian gogiids (Eocrinoidea, Echinodermata) from Guizhou Province, China. Paleontological Journal 43(11), 1406-1414. DOI 10.1134/S0031030109110057

PARSLEY, R.L. 2012. Ontogeny, functional morphology, and comparative morphology of Lower (Stage 4) and Basal Middle (Stage 5) Cambrian gogiids, Guizhou Province, China. Journal of Paleontology 86(4), 569-583.

DOI $10.1666 / 10-153 R 2.1$ 
Parsley, R.L. 2013. Development and functional morphology of sutural pores in Early and Mid-Cambrian gogiid eocrinoids from Guizhou Province, China, 79-86. In Johnson, C. (ed.) Echinoderms in a Changing World. Proceedings of the $13^{\text {th }}$ International Echinoderm Conference. University of Tasmania, Hobart.

Parsley, R.L. \& Prokop, R.J. 2004. Functional morphology and paleoecology of some sessile Mid-Cambrian echinoderms from the Barrandian region of Bohemia. Bulletin of Geosciences 79(3), 147-156.

Parsley, R.L. \& Zhao, Y. 2006. Long stalked eocrinoids in the basal Mid-Cambrian Kaili Biota, Taijiang County, Guizhou Province, China. Journal of Paleontology 80(6), 1058-1071. DOI 10.1666/0022-3360(2006)80[1058:LSEITB]2.0.CO;2

Prokop, R.J. 1962. Akadocrinus nov. gen., a new crinoid from the Cambrian of the Jince area. Sborník Ústředního ústavu geologického, Oddíl paleontologický 27, 31-39.

Prokop, R.J. \& FatKa, O. 1985. Luhocrinus monicae gen. et sp. nov. (Eocrinoidea) from the Mid-Cambrian of Bohemia. Věstník Ústředního ústavu geologického 60(4), 231-234.

Sмiтh, A.B. 1984. Classification of the Echinodermata. Palaeontology 27(3), 431-459.

SpRINKLE, J. 1973. Morphology and evolution of Blastozoan Echinoderms. 283 pp. Harvard University Special Publication, Museum of Comparative Zoology, Cambridge, Massachusetts. DOI 10.5962/bhl.title.66379

Sprinkle, J., Parsley, R.L., Zhao, Y. \& Peng, J. 2011. Revision of lyracystid eocrinoids from the Mid-Cambrian of South China and Western Laurentia. Journal of Paleontology 85(2), 250-255. DOI 10.1666/10-072.1

ŠNAJDR, M. 1958. Trilobiti středního kambria Čech. Rozpravy Ústředního ústavu geologického 20,1-280.

ŠUf, J. 1928. Report on Mid-Cambrian faunistical levels of the Jince Beds at the Vinice near Jince. Věstník Státního geologického ústavu Československé republiky 4(4-5), 129-133.

Ubaghs, G. 1967. Eocrinoidea, S455-495. In Moore, R.C. (ed.) Treatise on Invertebrate Paleontology. Part S, Echinodermata 1(2). Geological Society of America, Lawrence.
Ubaghs, G. 1975. Early paleozoic echinoderms. Annual Review of Earth and Planetary Sciences 3, 90.

DOI 10.1146/annurev.ea.03.050175.000455

Ubaghs, G. \& Vizcaĩno, D. 1990. A new eocrinoid from the Lower Cambrian of Spain. Palaeontology 33(1), 259-256.

Weidner, T. \& Nielsen, A.T. 2013. A highly diverse trilobite fauna with Avalonian affinities from the Mid-Cambrian Acidusus atavus Zone (Drumian Stage) of Bornholm, Denmark. Journal of Systematic Palaeontology 12(1), 23-92. DOI 10.1080/14772019.2012.740080

YAKOVLEV, N.N. 1956. Pervaya nakhodka morskoy lilii v kembrii SSSR (First find of crinoids in the Cambrian of SSSR). Doklady Akademii nauk SSSR 108, 726-727.

ZAMORA, S., DARroch, S. \& RAHMAN, I.A. 2013. Taphonomy and ontogeny of early pelmatozoan echinoderms: a case study of a mass-mortality assemblage of Gogia from the Cambrian of North America. Palaeogeography, Palaeoclimatology, Palaeoecology 377, 62-72.

DOI 10.1016/j.palaeo.2013.03.009

Zamora, S., Lefebvre, B., Álvaro, J.J., Clausen, S., Elicki, O., Fatka, O., Jell, P., Kouchinsky, A., Lin, J., Nardin, E., Parsley, R.L., Rozhnov, S., Sprinkle, J., Sumrall, C.D., Vizcaïno, D. \& Smith, A.B. 2013. Cambrian echinoderm diversity and palaeobiogeography, 157-171. In HARPER, D.A.T. \& Servais, T. (eds) Early Palaezoic Biogeography and Palaeogeography. Geological Society Memoir 38. DOI 10.1144/M38.13

Zhao, Y.L., Huang, Y.L. \& Gong, X.Y. 1994. Echinoderm fossils of Kaili Fauna from Taijiang, Guizhou. Acta Palaeontologica Sinica 33(3), 350-334.

Zhao, Y.L., PARsley, L.R. \& Peng, J. 2007. Early Cambrian echinoderms from Guizhou Province, South China. Palaeogeography, Palaeoclimatology, Palaeoecology 254(2), 317-327. DOI 10.1017/S0016756807003901

Zhao, Y.L., PARsley, L.R. \& Peng, J. 2008. Basal Mid-Cambrian short-stalked eocrinoids from the Kaili Biota: Guizhou Province, China. Journal of Paleontology 82(2), 415-422. DOI 10.1666/06-041.1 